\title{
オブジェクト共有空間を用いた並列遺伝的アルゴリズムにおける ノアの箱舟戦略の祫討
}

\author{
Consideration on $\mathbb{N o a l h}$ 's Ark Strategy
}

in Parallel Genetic Algorithm with Object-shared Space

\author{
飯村 伊智郎* 池端 伸哉 $†$ 中山茂 $*,+$
}

Ichiro IIMURA Shinya IKEHATA and Shigeru NARAYAMA

\begin{abstract}
遗伝的アルゴリズム (genetic algorithm: GA)には，集団内で同じ個体が急増するなどし

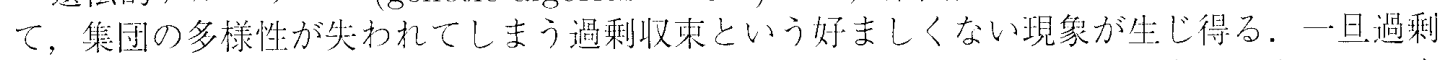

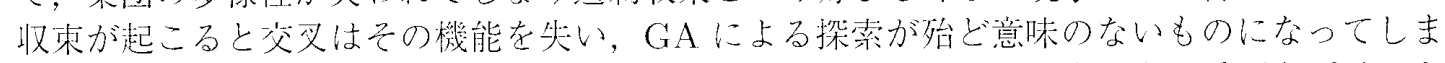
う。この過剩取束を回避して多様性を維持することが，GA 適朋する際の重琵なポイント となる。本論文では，まず，並列 GAの実装形態として，柔軟な分散並列処理の椿贸を提供

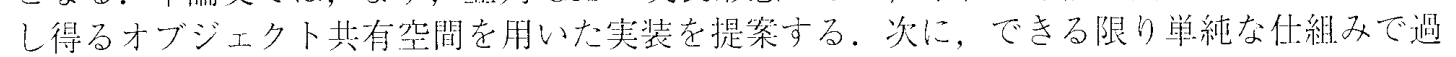
剩收束を回避する乎法として，並列 GAに抢けるノアの箱府戦略を提案し実験によりその有 朋性老明らかにする。この手法は，進化の停滞した部分集时の個体の多どを探紫解然間から 新たに迎え入れた個体群と入れ換えるものであり，非同期に均質個体を御汰し集団の多様性 減少に制限をかけることで過剩収束を回避する。
\end{abstract}

In a genetic algorithm (GA), the undesirable phenomenon of excess convergence can often occur. Excess convergence is the phenomenon where the diversity of a group is lost. This phenomenon occurs because homogeneous individuals are increased rapidly in the group while searching. Therefore, a crossover loses its function. Once the excess convergence occurs, the search by the GA becomes meaningless. It then becomes important in the adaptation of the GA to avoid this excess convergence and maintain the diversity. First, we show an implementation of a parallel GA based on a multiple group type island model by using object-shared space. Next, as an effective method for avoiding the excess convergence in a simple mechanism, we propose the diversity maintenance technique based on selection of the homogeneous individuals called Noah's ark strategy in parallel GA, and clarify the effectiveness on the knapsack problem. Our proposed method is to replace the individuals of sub-groups having the excess convergence with the new individuals coming from the search space. That is, we avoid the excess convergence by expelling homogeneous individuals asynchronously except for Noah who is an elite individual, and limiting a decrease of the diversity of the entire sub-group.

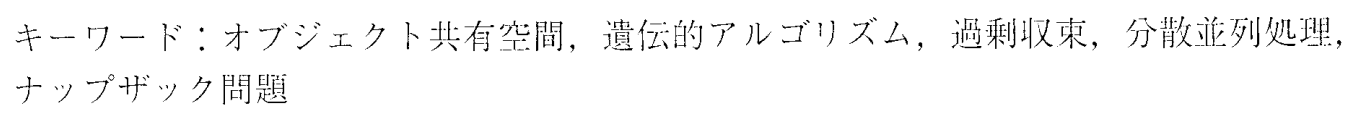

Object-shared space, Genetic algorithm (GA), Excess convergence,

Distributed parallel processing, Knapsack problem

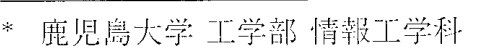

Department of Information and Computer Science, Faculty of Engineering, Kagoshima University

iimura@pu-kumamoto.ac.jp
†日立ソフトウェアエンジニアリング(株) Hitachi Software Engineering Co., Ltd. ike@aqu.hitachi-sk.co.jp

* shignaka@ics.kagoshima-u.ac.jp 


\section{$\mathbb{1}$ はじめに}

遺伝的アルゴリズム (Genetic Algorithm: GA)は, 巽択, 交文, 突然变異などの生物谁 化の原理に着想を得たアルゴリズムである。 現在では, 確率的探装, 学畾, 最適化の一手法 として, 科学分野から工学分野, ビジネス分 野，社会分野など数多くの分野に応用されて いる[1][2]。しかし，GAにはその進化 (探索) 在非効辫的なものにしてしまう瀜剩取束とい う好ましくない現象が生しじ得る。過䣋收束と は，集団内で同じ個体が急激に増加するなど して，集団の多様性が失わ机てしまう現侜で ある。このため，一旦渦剩収束が起こると交 义はその機能を头い，GAによる探䕀がほとん ど意味のないものになってしまう。言い換え れば，この過剩収束を回避して多様性を維持 することが，GAを適用する際の重琶なポイン 卜となる。多峰性を有する関数の最適化問題 などのより複雑な問題に対しては，多くの個 体が局所解に陷ることにより，容易に過剩収 束現象が生じ得る。そのような場合には，新 たな個体在生成する交义や突然変異，そして 適応度に基づく選択の強さ (湟汰圧) をうまく バランスさせ得る構成が不可欠であるが，そ れらは問題に応じて試行錯倸的に行わなけ犳 ばならない。

一方，GA は备々の㟠体が独立に進化できる 仕組みをもって扮り高い並外性を秘教ているこ とから，GAの高速計算を主眼としてその並列 化に関古る研究が数多く報告されている[3].

GAの並列化モデルの一つである複数集団型 には，並列化による計算時間の短綰の他に，進 化が局所的に進むので，集団全体としての多 様性を維持する效果があり過剩収束を回避し やすい，という特徽がある。ここで各部分集 団が全く独立であるならば，GAを複数回実行 するのと同じである。したがって，多様性維 持を目的とした往来の研究では，部分集団間 で個体の交換をどのように行うのか，すなわ ち移住方法が中心課題であった[4][5][6][7][8][9]. 本研究では，個体移住の仕方にはこだわらず， できる限り単純な化組みによる多様性維持の
実現を目指京。

本論文では，まず，並列遺伝的アルゴリズ ム (並列 GA. Parallel GA: PGA) の実装形態 として，オブジェクト指向型 Java 言語で実装 された Linda モデル[10]であるオブジェクト 共有空間 JavaSpaces ${ }^{[11][12]}$ 老用いる方法を提 穼する。 Linda モデルはタプル笔間と呼ばれ る抽象空間老用いて抢互いの情報伝澾を行う ので，特定の相手老明示的に指定して通信す る必要がなく，柔軟な分散並列処理の実装に 適している。そのJava言語による実装である オブジェクト其有空間 JavaSpaces は, データ とコードを会むオブジェクトという情報単位 在貯闇する空間であり，オブジェクトのデー タベースとは異なり，オブジェクトの流机を 作り出すことができ，またりースと呼ばれる オブジェクトの寿命をミり秒単位でもたせる ことなどもできる。つまりオブジェクト其有 空間は，才ブジェクトのためのネットワーク 上からアクセス可能な其有の貯蔵厙 (其有メ モリ)でありここで述べるようなデー夕处 理にも利用できる。次に，提案するオブジエ クト共有空間を用いた複数集団型島モデル並 列 GAに拈いて，組み合わせ最適化問題の典 型であるナップザック問題を題材に取り上げ， 文献 [4]などで既に指摘されているエリート個 体移住による多様性維持の効果，および探索 解空間拡大による多様性維持の効果を確認す る予備実験を行い，渦剩収束回避の必琶性を 示す。最後に，できる限り単純な仕組みで過 剩収束回避老実現する手法として，均質㑑体 の淘汰に上る多様性維持手法老提案しその有 用性孝示す。この手法は，谁化の停满した部 分集団のエリート個体以外の均質個体在，探 素解空間から新たに迎え入れた個体群と入れ 換えるものであり，一様化した個体群を御汰 し集団の多様性隇少に制限をかけることで過 剩收束を回澼する。 


\section{2 並列遺伝的アルゴリズム}

GA は，巽択，交叉，突然变異といった遺伝 的操作や各個体の適応度計算孝何世代にもわ たって行うため，膨大な計算量が必要とされ る。しかし，各個体は同時並行に遺伝的操作 や適応度計算在実行することができ，GAは证 列性の高いアルゴリズムであるといえる。そ のため，GAの高速計算を主眼として，様々 な並列化モデルが提案されており次の 2 つに 大別される。

単一集団 (単純並列) 型 GA 最適化計算に 㐫用古る場合，各個体の適応度は他の個 体の適応度とは独立に計算可能である. この点に注目して，適応度関数の評洒を 並列処理することにより高速化を四るも のが単一集団型である。皇の構成図を図 1 に示す。この単一集団型には, 選択, 交 叉, 突然変異といった遺伝的操作を 1 つの マスタプロセッサに集中させるため，同 型を適応度評值に要する時間が比較的短 い問題に適用した場合には，これらの遺 伝的操作を担うプロセッ⿻の負荷やこの プロセッサに集中するプロセッサ間通信 の負荷により並列化の効果が制限されや すい欠点がある。

複数集団 (分解) 型 複数集団型では, 集団がい くつかの部分集団に分割され，それぞれ の部分集団に対して独立に遺伝的操作が 適用される方式である島モデル (粗粒度

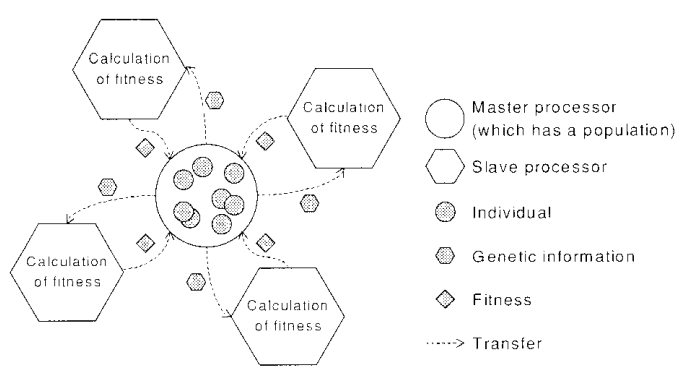

図 1 単一焦団型 GA

(マスタプロセッサは集扴に刘して遺伝 的操作を実行し，各スレーブプロセッサ は個体の適応度を計算する)
の並列 GA とも呼ばれる)，および各個体 がその近傍内の限られた個体としか相互 作用しない方式である近傍モデル(細粒 度の並列 GA とも呼ばれる) が提案され ている。島モデルでは，各プロセッサに 割り当てられた部分集団の内部で独立に 遺伝的操作が適用されるので，各々のプ ロセッサで独立性の高い進化が進められ ること，すなわち集団全体としての多様 性が高く保たれることが期待できる。し かし，各部分集闷が全く独立に進化する のであれば，GAの処理を複数回繰り返 すことと同じであり，この島モデルでは 部分集団間で個体を交換し互いに刺激し 合うことで効率的な探索を目的とした移 住という特徵的な操作がある。その構成 図在図 2 に示古。

筆者らは，その島モデルの特徴に着目し，ま た 3 節で述べるオブジェクト共有空間やワー 力複製形式との親和性の観点加ら，GAの並列 化モデルとして複数集団型島モデルを用いた。

\section{3オブジェクト共有空間を用いた ワーカ複製形式による複数集団型 島モデル並列 GAの実現}

オブジェクト共有空間 JavaSpacesは, Linda モデルをもとに開発されたもので，エントリ と呼ばれる型付けされたオブジェクトを格納 するタプル空間を提供する。その共有空間に

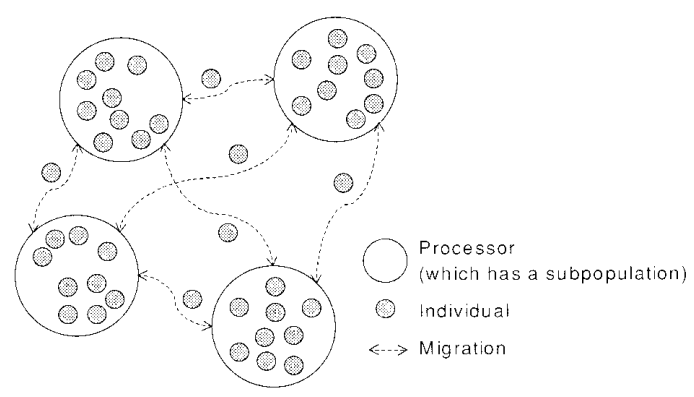

図 2 複数集団型鼠モデル GA

(各プロセッサは部分集団に対して遺伝

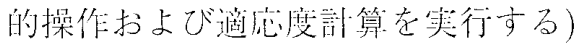


対してエントリを書き込む，読み取る，取り 去るなどの操作を行える。計算機 A が計算機 Bに対して処理を依頼するメッセージを送信 する場合を，オブジェクト共有空間を朋いて 实現すると次のようになる。まず，A が送る メッセージを含むエントリをオブジェクト其 有空間に書き达志。そして，Bは同一の型情 報をもつエントリを用いて，オブジエクト共 有空間に書き込ま机たエントリを取り去る。 この 2 つの処理により，Aから Bヘメッセー ジが送信されたことになる。また，オブジェ クト其有空間では，エントリの型や特定した 值が一致すれば，どの計算機でも同じエント リを取り出すことが可能である。よって，て のメッセージの依頼を処理できる別の計算機 $\mathrm{B}^{\prime}$ が，そのエントリを取り出して処理を行っ ても構わない。このようにオブジエクト共有 空間は，特䇥の相手を明示的にIPアドレスで 指定して通信する必要はなく，禿乾なシステ ムの記述が可能である。

筆者らは分散並列処理を行うために，ワー 力複製形式 [11][12] と呼ばれる処理形式を用い る。この形式では，処理をマス夕部分とワー 力部分とに分ける。マス夕は処理全体の制御 を行い, 仕事を分割してワーカに配り，ワーカ から処理結果在収集する。ワーカは割り当て られたデー夕に対して演算处理を行い，その 処理結果をマス夕に返方のみである。演算刘 像とする複数集団型鳥モデル並列 GA(以下， Island GA と略す) が $N$ 個の島 (部分集団) か らなるとき，ワ一カによる遺伝的操作や適応 度計算は $N$ 個の島每に独立して行える。この ワーカの役割を複数の計算機に行わせること により，分散並列処理が実現される。この形 式は，大量のデー夕に同一処理を施すことが 有効な数值計算, 画像処理, 情報検索などに も态用されている。

図 3 は，オブジェクト其有空間を用いたワー 力複製形式の概念図である。マス夕は初期母 集団在生成しそれらを複数個の部分集団に分 割して，そ机在内容にもつ仕事エントリ（同図 ではTask entryと示す) をオブジェクト其有

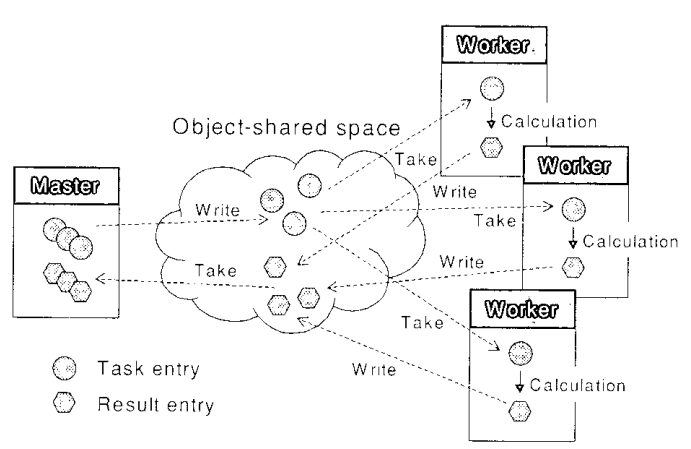

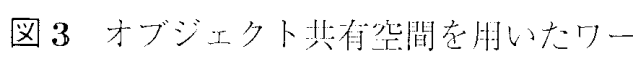
力褐輁形式

空間に書き迟む。そして，オブジェクト共有 空間を監視し，最良個体をもつ結果エントリ (同図ではResult entryと亦す)が各ワーカに より書き达まれたならば，そのエントリを才 ブジエクト共有空間から取り去る。一方，各 ワーカはオブジェクト共有空間を監視し, 部 分集団を内容にもつ仕事エントリがマス夕に より書き迟ま机たならば，そのエントリを才 ブジェクト其有空間から取り土る。そして， その情報をもとに，選択，交叉，突然变暴な どの遗伝的操作と適応度計算在行い，処理の 結果得られた最良個体をもつ結果エントリを オブジェクト其有空間に珰き込む。これらの 処理老あらかじめ指定した世代数分繰り返す と, 分散证列処理部分は完了となる。ここで, 准化の過程に関するデー夕採取が必要な場合, 最良個体を内容にもつ結果エントリを各ワー カがオブジェクト其有空間に每世代書き込み, それをマス夕が每世代取り去る必琶がある。 しかし，最終結果のみ必要な場合は，これら の処理は最終世代のみ行えばよい。 オブジェ クト共有空間は,このように最良個体の一時 格納を行うほか, 移住時の移民の一時格納も 行う.

オブジェクト共有空間を用いたワーカ複製 形式では，前述の通り特定の相手老 IP アド スで指定して通信する必要がないため，容易 にワーカを追加しその分散並列処理能力を问 たできる。また，オブジエクト指向型 Java 言 語の特徴によるものではあるが，てれにより 実装されたオブジェクト共有空間を用いるこ 
とで，CPUやOSの異なった種類の計算機を 組み合わせた柔軟な分散並列処理の構築が容 易に行える。

次に，オブジェクト共有空間を用いたワー 力複製形式に上る Island GA の時系列的な処 理の流机を図 4 に示す。この図は, 各部分集団 の進化の過程を見るために, 各ワーカが結果 エントリをオブジエクト共有空間に毎世代書 き迟み，それをマスタが每世代取り去る処理 を含めたものである。マス夕とワーカは，そ れぞれオブジェクト共有空間の依頼クライア ントクラス，計算クライアントクラスのオブ ジェクトである。また，マス夕，ワーカ，そし てオブジェクト共有空間老行き来するダブル クオーテーションで囲まれたエントリは, Java 言語の net.jini.core.entry.Entry インタ フェースを組み込んだクラスとして実現され たオブジェクトである。まず各ワーカは，自 分の存在を示㐫ためのWorkerFlag エントリを オブジェクト共有空間に書き込む。このエン トリの存在が, ワーカ数の柔軟な変更を可能 にしている。マスタはオブジェクト共有空間 を監視し，全てのWorkerFlagエントリを取り 去る。その後, マス夕は初期母集団老生成し, 取得したWorkerFlag エントリ数にその初期母 集団を分割して初期部分集団を生成し，それ らをオブジェクト共有空間に書き込む。した がって，ここでは部分集団数とワーカ数は等し いものとする。各ワーカはオブジェクト共有 空間を監視し，マスタにより書き迟まれたいず れか 1 つの初期部分集団を取り去る。マスタ は全ての初期部分集団がワーカにより取り去 られたことを確認すると，第 $i(i \geq 1)$ 世代の 開始を意味する $i$-thGenStartSignal エントリを オブジェクト共有空間に書き迟む。各ワーカ は，この $i$-thGenStartSignal エントリを読み込 むことで 1 世代分の処理を開始する。まず，前 世代に書き达ま机た移民である MigrantForithGen エントリのいずれか 1 つをオブジェク 卜共有空間から取り込克。その際，出身の島 と移住先の島とが䔬なるようにする。この条 件を満たす移民がない場合や，第 1 世代目に

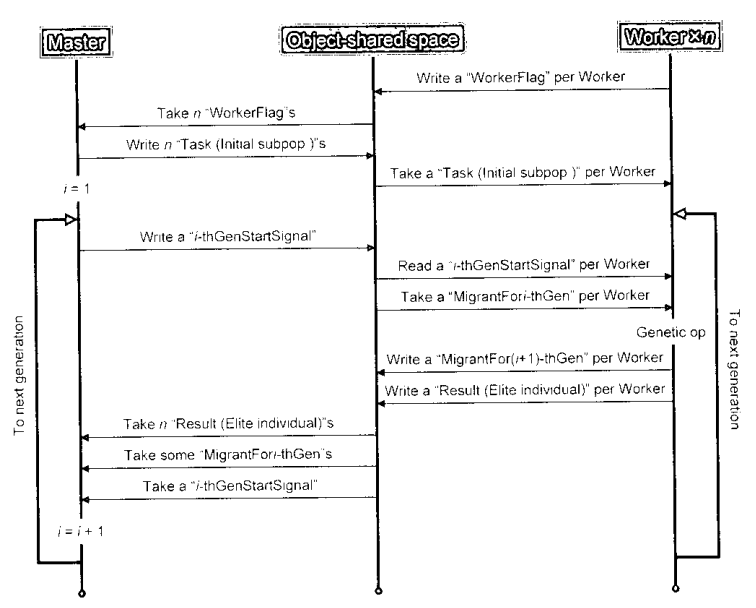

図 4. 将系列的な処理の流れ

おける移住のように前世代に移民が書き込ま れていない場合，この移民の取り迟みは行わ ない。取り迟んだ移民は，部分集団内の適忍 度が最も低い個体と置き換えられる。次に， 選択, 交差, 突然变異の遺伝的操作を行い, その結果得られたエリート個体の複製を次世 代の移民 MigrantFor $(i+1)$-thGen エントリと してオブジェクト共有空間に書き远む。した がって，移住による部分集団内の個体数の变 化はない。また，エリート個体の複製は結果 Resultエントリとしても書き込まれる。これ で各ワーカの 1 世代分の処理は終了となる。 マスタはオブジェクト共有空間を監視し, 各 ワーカからのResultエントリを取り去る。全 ワーカからの Result エントリを取り去ると, 次にオブジェクト共有空間に残っているいく つかの MigrantFori-thGenエントリを取り去 り消去する。最㖟に，i-thGenStartSignal エン トリを取り去る。この時点で，マス夕には各 ワーカのエリート個体が存在し，その中で最 も適応度の高いエリート個体がこの世代の最 良個体となる。次に，マス夕は世代を表亦 数 $i$ をンクリメントし，第 $i$ 世代の開始を 意味するi-thGenStartSignal エントリをオブ ジェクト共有空間に書き込む。以降同様の処 理を繰り返し行い，あらかじめ指定した世代 数に達すると処理は終了となる。ここで，マ ス夕により生成された部分集団を内容にもつ エントリを各ワーカが取得し GAの処理を開 
始すると，その後のオブジェクト共有空間に 刘するアクセスは，フラグや最良個体，ある いは移民老内容にもつ小さなエントリのみで あり，部分集団自体を内容にもつ大きなエン トリが各世代再に行き来することはないこと に注意したい。

\section{4 実験}

本節では，前節で提案したオブジェクト共 有空間を朋いたワーカ複製形式による Island GAに扮いて，組み合わせ最適化問題を題材 に取り上げ，文献 $[4]$ などで既に指摘されてい るエリ一ト個体移住による多様性維持の效果, 㧍よび探索解㤎間桩大による多様性維持の効 果老確認する予備実験を行い, 满剩収束回避 の必赑性老示市。次に，その過剽収束回避を 奏現する手法として，均質個体の湟汰に上る 多様性維持手法存提案しその有用性在示古。

\section{1 対象とした組み合わせ最適化問 題}

実験対象とした組み合わせ最適化問題は, ナップザック問題 (Knapsack Problem: KP) である。Lを品物の数, $a_{j}$ と $c_{j}$ を品物 $j(j=$ 1，2，，L）の重量と䛧值，そしてナップ ザックの重量制限をbとすると, KP は次式 で定義される[13]。ただし， $x_{j} \in\{0,1\}$ であ $\eta, a_{j}, c_{j}, b$ 証数とする。

$$
\begin{aligned}
& \text { 目的関数 } z=\sum_{j=1}^{L} c_{j} x_{j} \Longrightarrow \text { 最大化. } \\
& \text { 制約条件 } \sum_{j=1}^{L} a_{j} x_{j} \leq b .
\end{aligned}
$$

すなわち, KPは重量制限bのもとで, 総洒 值えを最大にするように品物jをナップザッ クに詰める問題である。G における $\mathrm{KP} て ゙$ は，単に $L$ 個の品物の有無を並べた 0,10 文字列在遗伝子型として実現できる。つまり 染色体 Cは,

$$
C=\left\{x_{1}, x_{2}, x_{3}, \cdots, x_{L}\right\},
$$

となる。ここで各 $x_{j}$ は止述の通り0または 1 の值をとり，1(0)の場合はその品物 jをナッ プザックに人机る(大れない)こと表す。

なお，実験に拈いては品物数 $L$ を500とし， 全品物の合計重量の 50 \% 在重量制临bとした。 また，品物 500 個分の重量と洒值からなる問 題デー夕は, 乱数で生成し, ファイル化して, 全実験に捛いて共通に使用した。その詳細に ついては，付録のA 節老参照していただきた い。实用性の観点からは, 評価吉る対象とし て実間題を取り上げるのがよいが，今回は乱 数生成した KP 在対象とした。問題データの 設定の仕方で多少の難しさは变動すると考元 られるが，過剩収束回避の必要性と，以降で 提案するノアの箱舟戦略の效果を見るには十 分であると思わ扎る。

\section{2 実験条件}

ここでは，徯述する3つの実験で用いた遺 伝的パラメー夕, 遺伝的操作, そして移住の 仕方について述べる。さらに，集団の多様性 在評価军る指標についても述べる。

\section{2 .1 遺伝的パラメータ}

最大世代数 $T$, 総個体数 $M$, 交珤梁 $p_{c}$, 突 然変異率 $p_{m}$ とし，また部分集団数 $N, 1$ 個 体中の遺伝子数 (KPに打け吕品物の数) $L$ と すると，実験で用いたIsland GAの遺伝的パ ラメータは表1に示す通りである。

\subsection{2 遺伝的操作}

選択には，世代 $t$ までに現れた最良個体を $m_{t}^{*}$ としたとき, 次世代の集団 $M_{t+1}$ に対して $m_{t}^{*}$ 老增殖し $\boldsymbol{M}_{t+1}$ 内の最も適応度の低い個 体を淘汰するエリート保存㟟択在採用し, 各部 分集団に対して適用した。また，交叉は，ラン ダムに選んだ 2 個体を対象に複数の交义位置 で遺伝子を引き継ぐ複数点交叉を用いた。実 験においてはその交文位蹎を2点とした。 らに垁然変異は，文字列の1箇所をランダム 
表 1 実験で使朋した遺伝的パラメータ

$\begin{array}{lll}\text { Max. generations } & T=500 \\ \text { Total individuals } & M= \begin{cases}500 & \text { (Pre. exp. 1, Exp. 3) } \\ 500 N & \text { (Pre. exp. 2) }\end{cases} \\ \text { Crossover rate } & p_{c}=1-\frac{3 N}{M} \\ \text { Mutation rate } & p_{m}=\frac{N}{L M}\end{array}$

表 2 实験で使用した計算機

\begin{tabular}{|c|c|c|c|c|}
\hline Function & $\mathrm{CPU}$ & $\mathrm{OS}$ & Ver. of JDK & Ver. of Jini \\
\hline Master & PentiumIII $500 \mathrm{MHz}$ & Windows 2000 & $1.2 .2-006$ & 1.0 .1 \\
\hline Worker $\times 30$ & Celeron $500 \mathrm{MHz}$ & Windows 98 & 1.3.0-C & 1.0 .1 \\
\hline JavaSpaces server & PentiumII $266 \mathrm{MHz}$ & Windows 98 & $1.3 .0-\mathrm{C}$ & 1.0 .1 \\
\hline
\end{tabular}

に選択し反転させる 1 点突然変異を使用した。

\subsection{3 移住}

移住は同期型を採用し，その条件は次の通 りである。なお，移住は 3 節で述べたオブジェ ク卜共有空間を介して行うものとする。

移住可能な部分集団 自集団以外のすべての部 分集団に対して移住可能とする。

移住を生じる世代間隔 移民の受け入れは毎 世代行うものとする。ただし，受け入れ 可能な移民が存在しない場合，移住は行 わない。

移住する個体数 部分集団の数と同じとする. つまり，1部分集団あたり 1 個体とする。 移住対象の個体 各部分集団に扮ける最も適応 度の高いエリート個体の複製老移住対象 すなわち移民とする。また部分集団に取 り迟まれた移民は，その部分集団内の適 応度が最も低い個体と置き換えられる。

\subsection{4 集団の多様性評価}

集団の多様性老評価する指標として，相異 なるスキーマ数の計測, Lost alleles, Percent, involvement，エントロピー，適芯度分布の標 準偏差 ${ }^{[7]}$ ，遺伝子-分布の重心から各個体まで の距離の分散 $[14]$ などがあげられる。実験で
は，この中でも比較的少ない演算量で評俩す ることができる適応度分布の標準偏差を用い た。この場合，適応度分布の標集偏差が高い 值孝示寸ほど集団の多様性が高く，また０に近 いほど集団の均質化が進んでいることを示す。

\section{3 実験環境}

3 節で述べたオブジェクト共有空間を用い たワーカ複製形式によるIsland GAの笑装に は，表 2 に示守計算機を使用した。総数 32 台 であり，その内訳はマス夕用計算機が 1 台， ワーカ用計算機が 30 台，オブジェクト共有 空間用計算機が 1 台である。使用ソフトウェ アは, Java 開発環境.JDK(Java Development Kit）とオブジエクト共有空間を提供する Jini である。

\section{4 エリート個体移住の効果 (予備 実験 $\mathbb{1}$ )}

\subsection{1 実験內容}

本実験は，多様性維持の観点から，移住を行 う場合と行わない場合に対して，部分集団数 $N$ が5，10，30の場合についてそれぞれ施行 し，それらの適応度の推移および多様性の推 
移を比較する。その際，各部分集団における 個体は，初期母集団在均等に分割配分寸るも のとする。すなわち，総個体数 $M$ が500であ るから， $N=5$ のとき各部分集団内の個体数 は $100, N=10$ のとき各部分集団内の個体数 は $50, N=300$ とき各部分集団内の個体数 は16(ただし，1部分集㳡のみ個体数が36とな る) となる。移住走行う場合の時系列的な処理 の流れは図 4 と同様であり，移住を行わない 場合は，四 4 に扔ける移住の操作であるTake a "MigrantFori-thGen" per Worker, Write a "MigrantFor $(i+1)$-thGen" per Worker, そして Take some "MigrantFori-thGen"s の処理が省 かれる。

\subsection{2 実験結果}

図 5, 図 6, 図 7 は，それぞれ部分集団数 $N$ が $5,10,30$ のときの备島の適応度推移を示 している，逼応度の值は，いずれも各島に招 ける最良個体のものを示している。移住がな い場合，Nの值に係わらず各島とも進化の早 期段階で局所解に陥り進化の停滞が認められ る。一方，移住ありの場合，移住なしほど早 い段階では過剩收東にはならず解の質を向上 させる傾向にあることがわかる。最終世代に 扔ける適芯度の平均值で比較すると，移住を 考慮することで，N=5のときは約 $14.2 \%$, $N=10$ のときは約 $18.4 \%, N=30$ のときは 約 $29.3 \%$ の改善が見られ，エリート個体移住の 効果が確認できる。また, 図 5 , 図 6, 図 7 に 対芯する多様性の推移をそれぞれ図 8, 図 9, 図10に示す。これらのグラフは，中心から在 側に移住ありの場合, 左側に移住なしの場合 の多様性推移在示しており, それらの縦軸は 4.2 .4 節で述べた適応度 (総価值 $z$ ) 分布の標準 偏差である。これらのグラフから，移住によ り多様性が維持される傾问にあることがわか る。これは，「だまし問題」のように大多数の 個体が最適解近傍から離れやすい場合には移 住をしないうが多様性の維持につながる場合 があるが，ナップザック問題のような問題空 間が比較的簡単な場合には，移住が多様性維 持に效果をもつこと在示している。遺伝的パ
ラメータや溃伝的操作などの最適化を行って いないため，今回は移住の有無に係わらず准 化の停滞が見られたが，これらの結果から，明 らかにエリート個体の移住は多様性維持の钼 点で有効であることが楒められ，文献 [4]など を裏付ける結果となった。

しかし，母集団の分割数を增やすほど各島 に属する個体数が減少するため，その結果多 様性維持能力が低減寸ることになり, それに よる過剩収束現象を防ぐ手法を娭討古べきで ある。

\section{5 探索解空間拡大の効果 (予備実 験 2)}

\subsection{1 実験内容}

多様性維持の観点で移住が有効であること を予借奏験 1 で確認したが，同時に過剩収束 回避の必要性も明らかになった。本䒠験では， 移住ありの Island GA 老対象として, 多様性 維持の観点から探索解空間桩大の効果を検証 する。計算機が多数用意できる場合，1台の ときと比べて単純計算で台数倍の演算能力を 提供できることになる。その演算能力を活朋 して，GAに㧍ける初期舟集河数老通常の台 数倍に増やすことによって同時に探索できる 解空間を拡大する。実験は，島分けの概念が ない単純 GA(Simple GA: SGA) と, 部分集 団数 $N$ が $5 ， 10 ， 300$ ときの Island GAに刘 して行い, それらの適応度の推移を比較する。 ここでは，予備実験 1 とは異なり初期母集団 は分割配分せず，初期时集団を複製したもの を部分集団としているため，各部分集団内の 個体数は部分集団数 $N$ に関倸なく500であ る。本実験の時系列的な処理の流れは，図 4 の Write $n$ "Task (Initial subpop.)"s が Write $n$ "Task (Copied initial pop.)"s, Take a "Task (Initial subpop.)" per Worker が Take a "Task (Copied initial pop.)" per Workerとなる, 市 なわち初期母集団そのものを複製して各ワー 力に与えるところが異なる。 


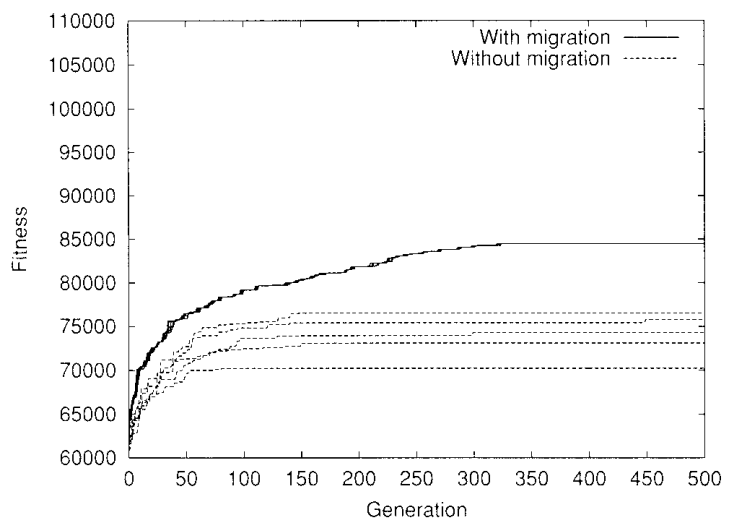

図 $5 N=5$ に拐汁万各島の適応度推移

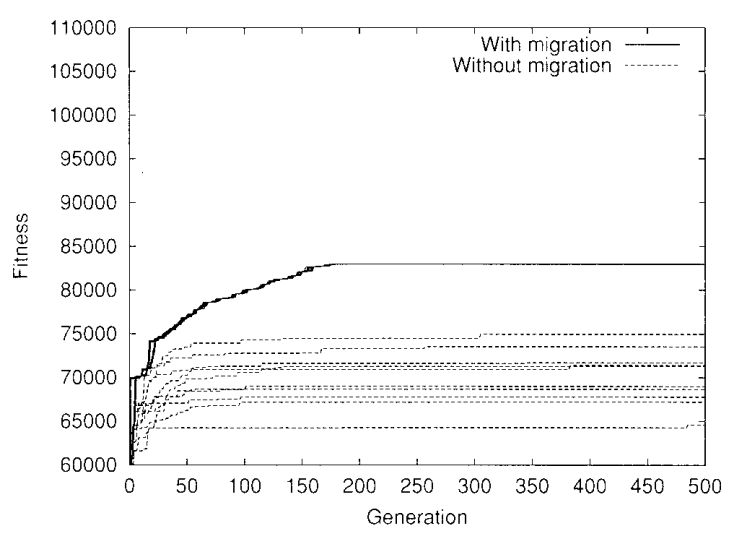

図 $6 N=10$ に抒ける各言の適応度推移

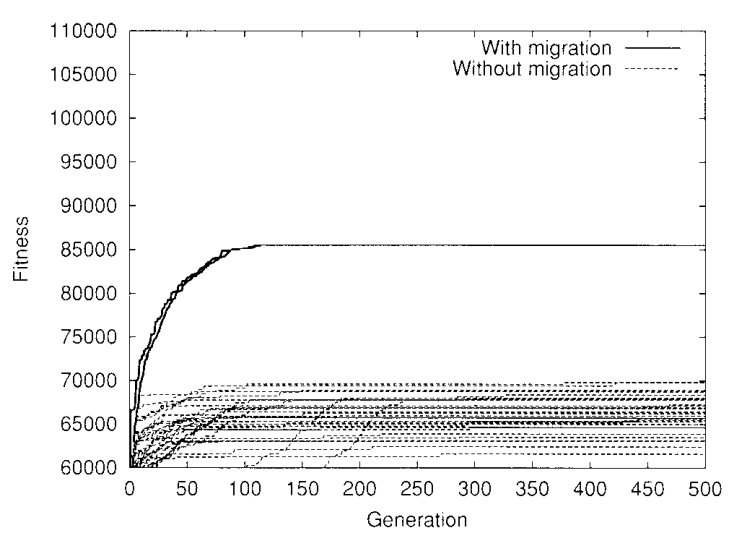

図 $7 \quad N=30$ に打忛万各島の適応度推移

\subsection{2 実験結果}

本実験では，初期母集団を分割せず初期団 集団を複製しそれらを部分集団とすることに よって探索解空間の拡大を図っている。その

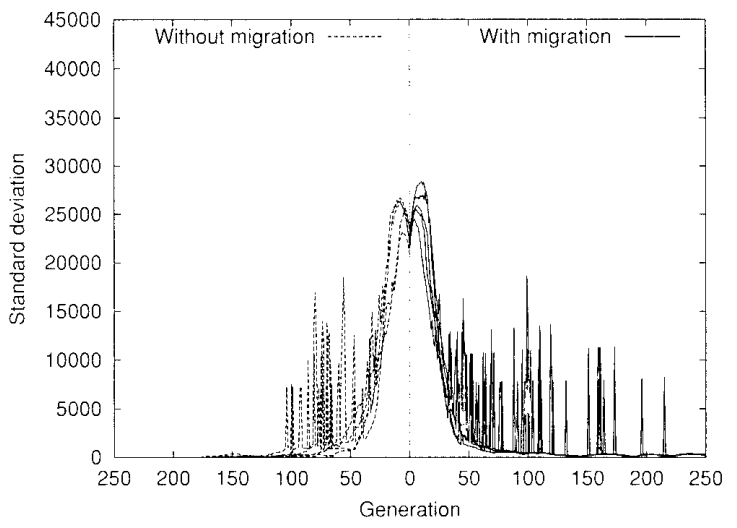

図 $8 N=5$ に扮ける各島の多様性推移

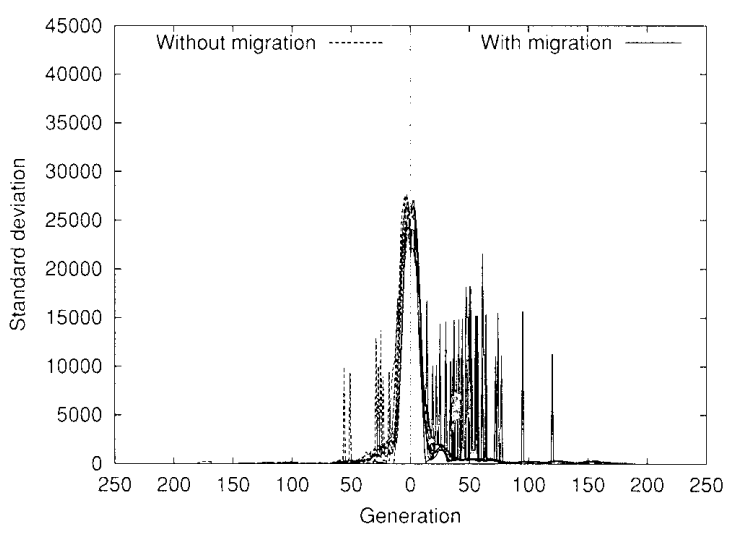

図 $9 N=10$ に打忛万各商の多様性推移

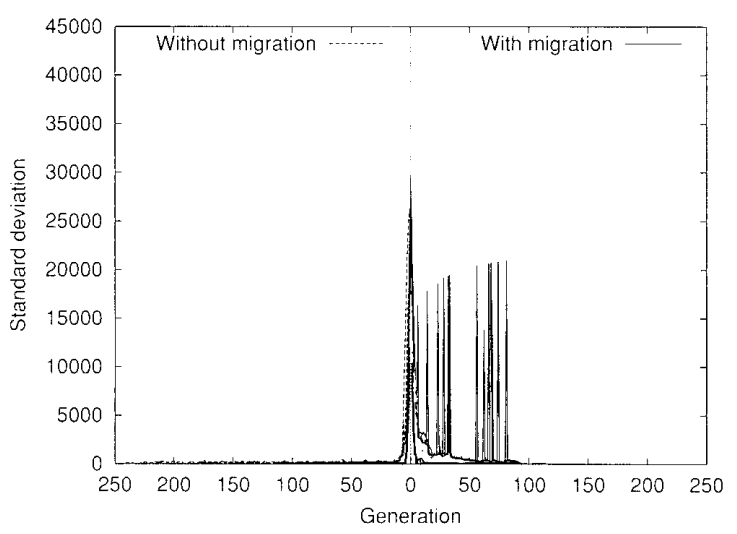

図 $10 N=30$ に拈忛万各監の多様性推移

ため，1 世代分の挆索解空間を $S$ とすると，部 分集団数が $N$ の場合 $S \times N$ の広さをもった 解空間老 1 世代で探素することができると考 えられる。四 11 は，比較対像としての SGA 


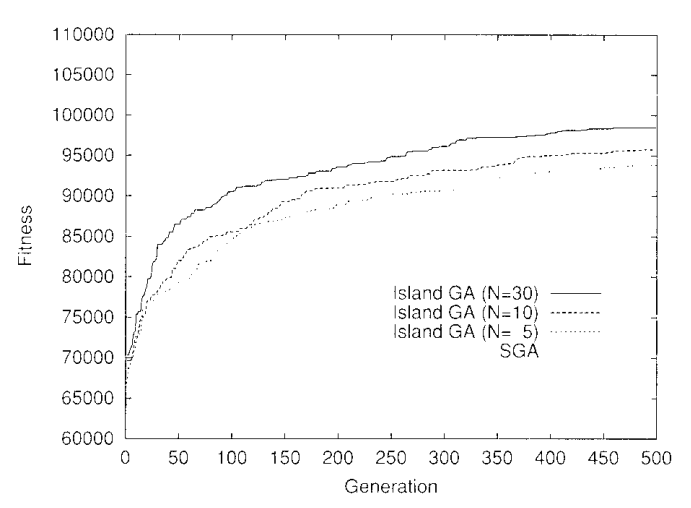

図 11 SGA と Island GA(移体市り, $N=5,10,30)$ の適応度推移

と, 部分勧団数 $N$ が $5,10,30$ のときの Island GAに抢ける適応度推移走示。適応度の值 は, SGA では最良個体のものを, Island GA で は島全体に扮ける最良個体のものを示してい る、最終世代に扔ける適応度で比較すると， 探索解些間在拡大寸ることで, SGA と比べ $N=50$ ときは約 $11.3 \%, N=10$ のときは 約 $13.6 \%, N=30$ のときは約 $16.9 \%$ 改善 が見られ，探索解空間搪大の效果が確認でき る。この結果から明らかなように, 探索解空 間の搪大は過剩权束を回避し解の質を问上さ せる傾向にあることが認められ，文献 [4]など 在襄付ける結果となった。

このように過剩収束回遊の傾向が確認でき るものの, 並列処理の日的の一つである処理 の高速化の钼点からは，このようなアプロー 千による過剩収束の回避は好ましくない。そ こで，篗者らはできる限り単純な仕組みで多 様性を維持し過剩収束老回避する手法を提案 し，笑験３に扮いてその有用性を検証した。

\section{6 提案する多様性維持手法の効果 (実験 3)}

\subsection{1 提案する多様性維持手法}

初期河集団を分割せず初期纬集団の複製を 部分集団として探素解空間の拡大老図ること により，多様性維持能力が向上することを予 備䒠験 2 で倠恋した。しかしこのアプロー
チは処理の高速化の钼点からは不利であるた め，他のアプローチによる多様性維持手法が 求められる。そこで筆者らは, 处理の高速化 の钼点から予備实験 1 の移住あり Island GA と同様に初期脢集団は均等に分割配分するも のとした。そして，進化の過程で停蓱加確認 された部分集㖥に属する個体のほとんどを探 索解䇥間から新たに迎え入れた個体群と入れ 換える，すなわち均質化した個体のほとんど を淘汰し集団の多様性減少に制限をかけるこ とにより渦剩收束を回避することを考えた。 ここで言うほとんどとは，対象となる部分集 団の最良な 1 個体 (エリ一下個体) 以外の個体 を指し，この㰸汰 ( 入元替え) の操作は各部分 集団で非同期に行われるものとした。滗者ら は，この最良な 1 個体を，旧約聖書創世記第 $6 ， 7 ， 8$ 章にある「ノアの箱舟」神話におけ るノアと考え，そのノアの影䈉によりさらな る解の改善在行门意味で鍌汰の対泉から外す ことにした。このようにノアを残すことによ り，最適解に近い解老ある程度速く探し出す ことも期待できる。多様性の評体には，既に 4.2.4節で述べたように適応度分布の標準偏养 を用い，今回の实験は各部分集団での標準偏 差が 1.0 未渾になったときを多様性が头われ たと見なし，最良な1個体以外の均質化した 個体群を，探索解空聞から新たに迎え入れた 個体群で淘汰するものとした。

ここで，准化が停滞した部分集団に対する 個体の入れ替え操作は，SGA を翼なる初期状 態から繰り返すこととほぼ同じように思われ るが, SGAにはノアが残らないこと,さらに は移住がないことに注意したい。進化が停膟 し存在意義の薄れた部分集団に対して入れ替 えを衍うことは，局所解に䍀ったノアに刺激 を与えさらなる解の改善を行うことを意味す る。また入替えによって与えられた刺激は 移住により進化中の他の部分集団に対しても 影響を与え，解のさらなる改善と多様性の維 持につながることを考慮すると，部分集団の 個体の入机替えは，SGA を異なる初期状態か ら繰り返すトリビアルな方法とは異なるもの 


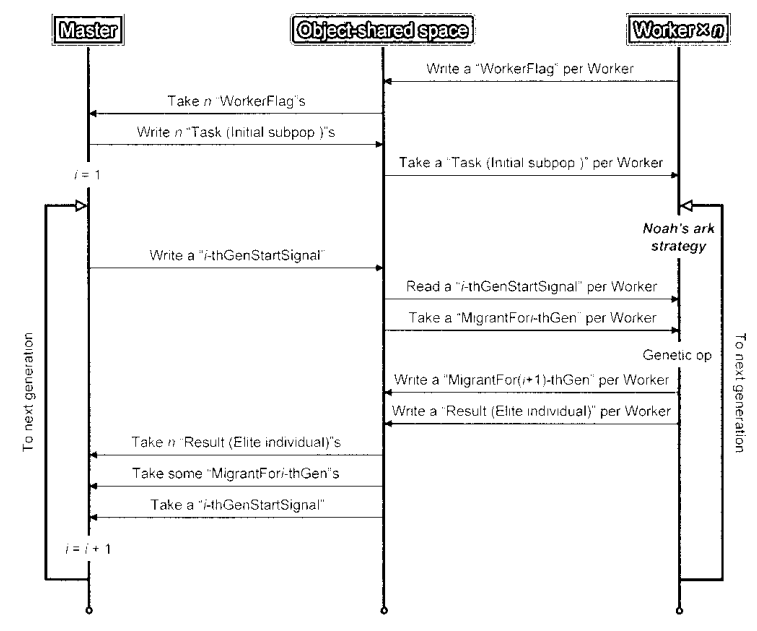

図 12 時采列的な処理の流れ(ノアの箱 䑢戦略在合屯)

と考えられる。ここでは，この提案する多様 性維持手法を「ノアの箱舟」神話にちなんで, 並列 GAに扔けるノアの)箱践略 (Noah's ark strategy) と呼ぶことにする。

このノアの箱舟戦略に似たような方法とし て，文献 [15]で提案されているマルチ個体群 方式の消滅亡生成がある。このマルチ個体群 方式では，淘汰率を異にした複数個の個体群 を準備し、マルチ山登り法に近い探索をして いる(吘汰率が低い) 個体群で見つかったスコ アの良い解を，最良優先探索に近い(淘汰率 が高い) 個体群へ移し，集中的な探装を行う。 その一方で, 消滅 (最もスコアの良い解と同じ スコアの解が個体群の半分を超えたら，その スコアの解の半分を捨てる) と生成 (解の多様 性が最も保存されていると考えられる淘汰率 0\%の個体群で繁殖を行い, 消滅によって減っ た個体数相当の個体老新たに生み出す)の処 理を行っている。このようにマルチ個体群方 式は，その実現が複雑になることは避けられ ない。一方ノアの箱舟戦略は，全ての部分集 时が全く同じ処理を行えばよく極めてシンプ ルなモデルであると考えられる。

オブジェクト共有空間を用いたワーカ複製 形式による Island GAの，ノアの箱舟戦略 を含んだ時系列的な処理の流れを図 12 に示 す。各ワーカは，まず自分の存在を示すため
WorkerFlagエントリをオブジェクト共有空間 に書き迟む。マスタはオブジェクト共有空間 監視し，全てのWorkerFlagエントリを取り 去る。その後，マス夕は初期成集団を生成し， それを取得したWorkerFlagエントリ数に分割 し初期部分集団老生成しオブジェクト共有空 間に書き迟む，各ワーカはオブジェクト共有 空間老監視し，マス夕により書き迄まれたい ずれか1つの初期部分集団を取り去る。マス 夕は全ての初期部分集団がワーカにより取り 去られたことを確認寸ると，第 $i(i \geq 1)$ 世代 の開始を意味する $i$-thGenStartSignal エントリ をオブジェクト共有空間に書き込む。各ワー カは，このi-thGenStartSignal エントリを娔み 込むことで 1 世代分の処理を開炲玄る。まず， 各ワーカは，ノアの箱舟戦略のために適応度 の標準偏差を評仙する。年の值が 1.0 以上の 場合は何もせず次処理に移る。1.0末満の場 合は，多様性が失われたと見なし，最良な 1 個体(ノア) 以外の均質化した個体群老, 探索 解空間から新たに迎え入れた個体群で海汰す る。ここで，偨索解空間から新たに迎え入れ られる個体群の生成は，該当するワーカがそ れぞれ行うものとする。次に, 前世代に書き 込まれた移民である MigrantFori-thGen エン トリのいずれか 1 つをオブジェクト共有空間 より取り迟む。以降の処理は, 四 4 と同様で ある。

\subsection{2 実験內容}

本実験では, 各部分集団の多様性を監視し, 多様性が失わ机た部分集団に属する最良な 1 個体以外の均質化した個体群を，探索解空間 から新たに迎え入れた個体群によって非同期 に淘汰することによる多様性維持手法，ノア の箱舟戦略について評洒する。ここでは，予 備実験 1 の移住あり Island GA(以下, 従来手 法と呼ぶ) と提案手法に対して, 部分集団数 $N$ が5，10，30の場合についてそれぞれ施行 し, 適応度の推移扮よび多様性の推移を比較 する。な招各部分集団内の個体数は，予倩実 験 1 の場合と同様である。 


\subsection{3 実験結果}

図 13 , 図 14 , 図 15 に, 部分集団数 $N$ が 5 , 10，30の場合の島全体の適応度推移を示京。 適忍度の值はいずれも島全体に扔ける最良個 体のもの走している。提案手法では，探索 解空間から新たに迎え入れた個体群による淘 汰が行わ机た直後はさらなる良質の解を探索 するのに時間がかかるため探索の進行は階段 状になるが, 従来手法と比較しいずれの場合も 局所解に陥らず解の探索が滞りなく進んでい ることがわかる。最終世代に拈ける適庶度で 比較すると，提案手法を用いることで，従来手 法と比べ $N=5$ のときは約 $3.0 \%, N=1.0$ の ときは約 $8.8 \%, N=30$ のときは約 $10.0 \%$ の 改善が見られ，ノアの箱舟戦略の效果が確認 できる。図 16 , 図 17 , 図 18 に, 部分集団数 $N$ が5，10，300場合の提案手法に扔ける各 島の多様性推移を示す。ここでグラフの縦軸 は，4.2.4節で述べた適応度分布の標準偏差で ある。予備実験 1 の図 8, 図 9, 図100右僛の グラフと比較することにより，提案手法は常に 多様性を維持しようとしながら探索を行って いることがわかる。また，図 19, 四 20, 四 21 に, 部分集団数 $N$ が $5,10,30$ の場合の島全体 の多様性推移を示す。グラフの縦軸は, 図 16 , 図 17 , 図 18 と同様である。いずれの場合も， 提案手法における島全体の多様性は従来手法 より高く保たれていることが碓認できる。最 終世代までの慗準偏差の平均值で比較寸ると, 提案手法は従来手法と比べ， $N=5$ のときは 約 3.8 倍, $N=10$ のときは約 16.0 倍, $N=30$ のときは約 68.9 倍と極めて高い多様性を示し たささらに図22に, 提䋈手法に扔ける部分集 団数 $N$ が $5 ， 10 ， 30$ の場合の島全体の適応度 推移を示古。適灾度の值は，島全体に打ける 最良個体のものを示している。この結果加ら 提案手法は, 過剩収束に上る進化の停滞が起 こりにくい負荷分散による高速化も期待でき ることがわかる。たたし，オブジェクト共有 空間を用いたワーカ複製形式による分散並列 処理では，タスク分割数によりシステム性能 に違いが生じることがわかっており，不必要に

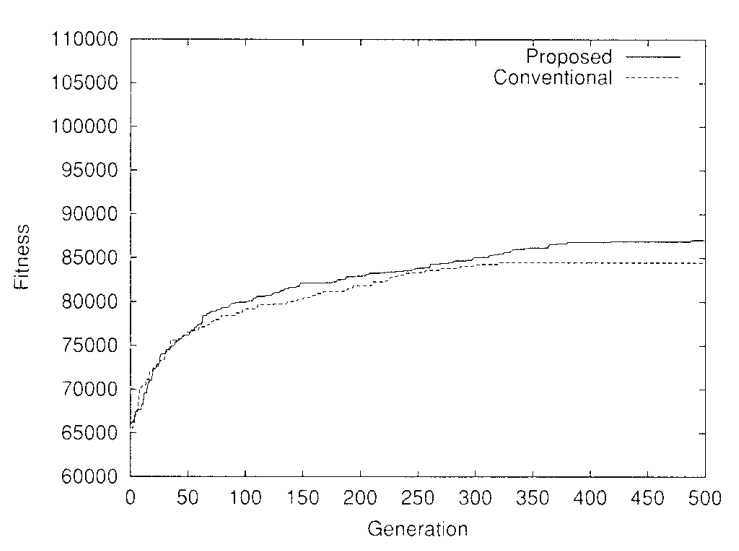

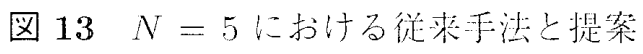
手法の鼠全体の適応度推移

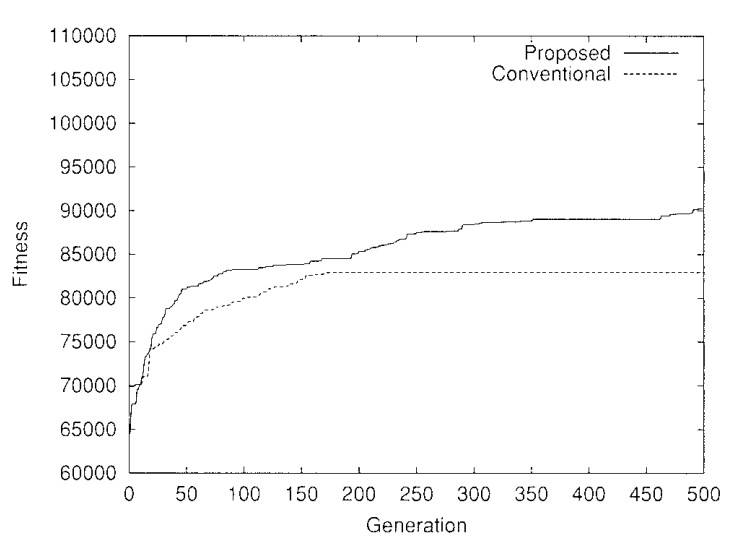

図 $14 N=10$ にお沙従来手法上提案 手法の島全体の適応度推移

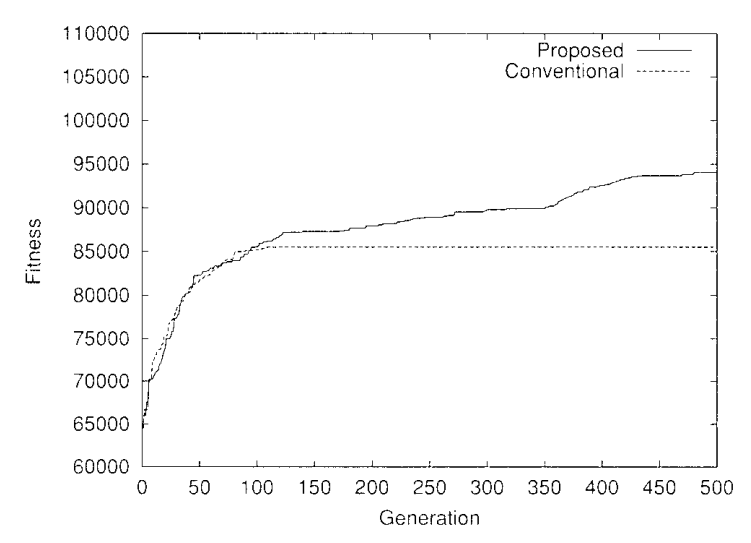

図 $15 N=30$ に拈け石彷决手法と提案 乎法の鼠全体の適灿度推移 


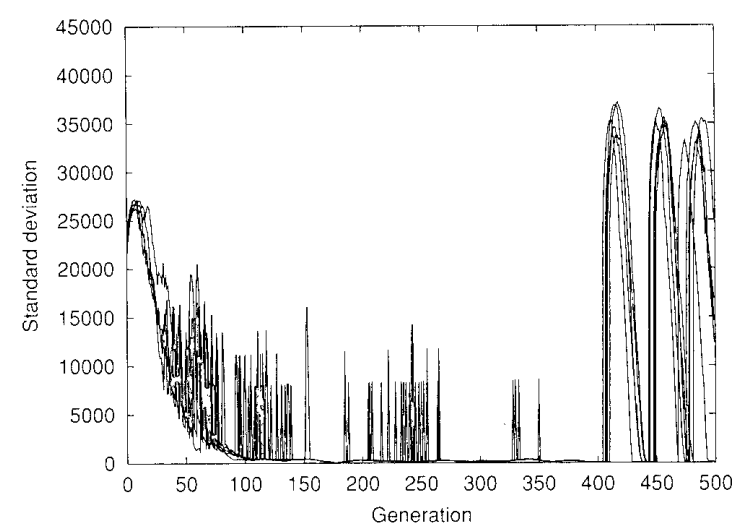

図 $16 N=5$ に打方提案手法の各島 の多様性推移

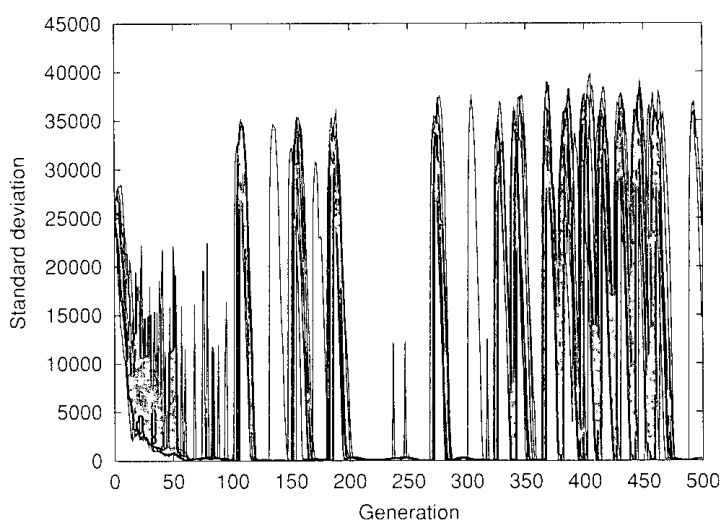

図 $17 N=10$ に拈方提案手法の各鼠 の多様性推移

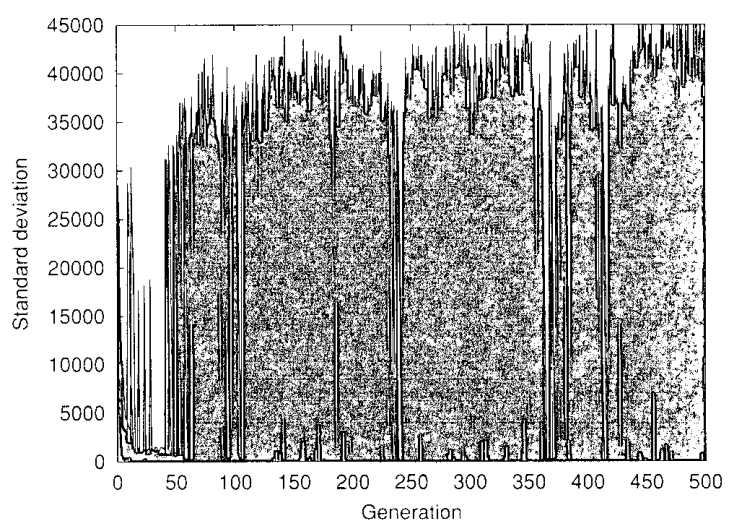

図 $18 N=30$ における提案手法の各島 の多様性推移

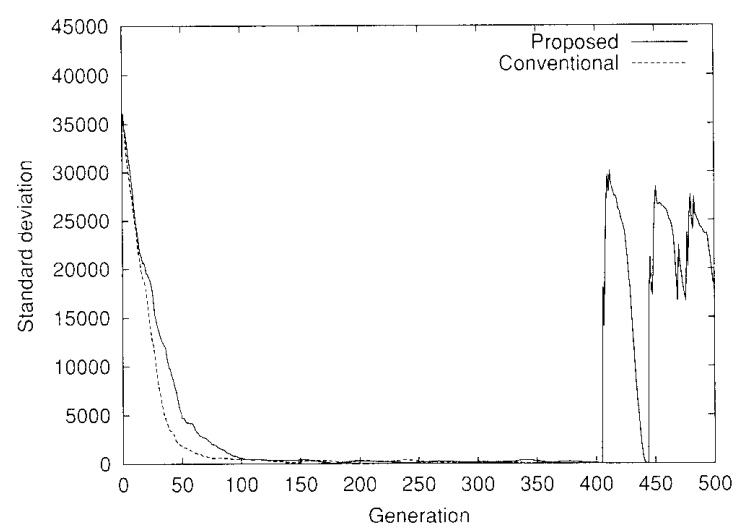

図 $19 N=5$ に打ける彷来手法と提案 手法の島全体の多様性推移

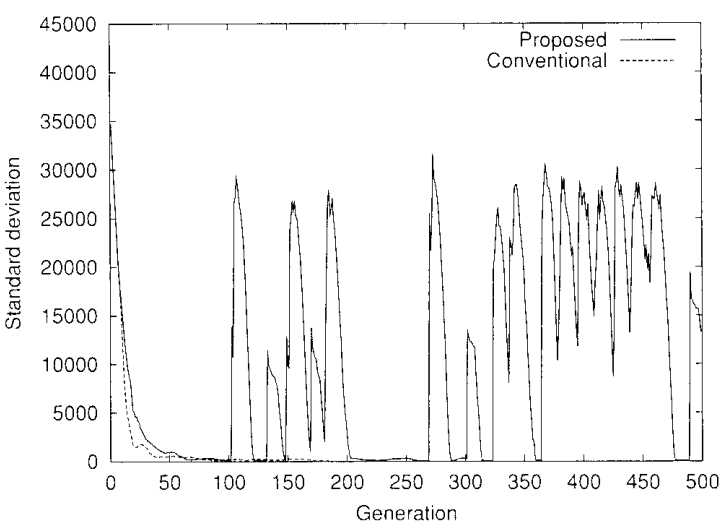

図 $20 N=10$ に打ける從来手法と提案 手法の島全体の多様性推移

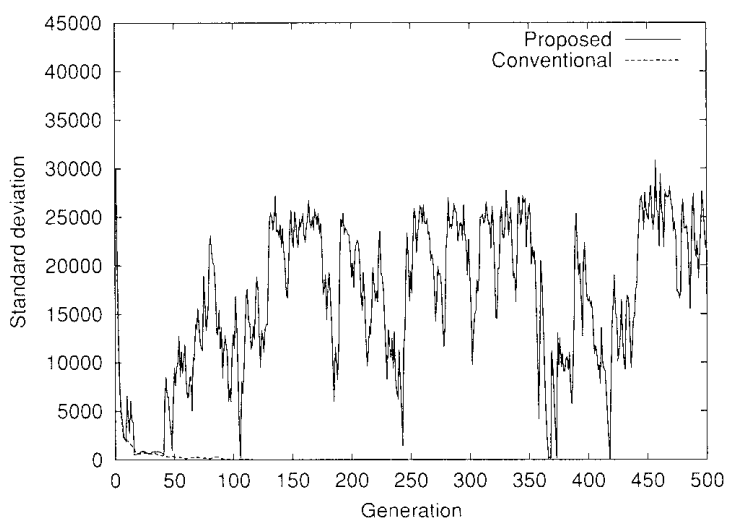

図 $21 N=30$ に打的従来手法と提案 手法の島全体の多様性推移 


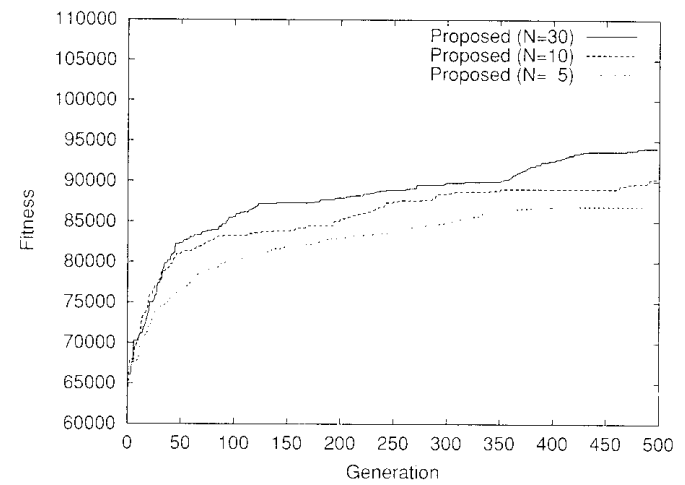

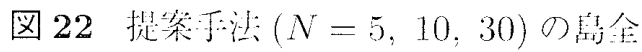
体の適纫度推移

部分集国数 (タスク分割数) を增やすことは, かえって性能低下につながる場合があること に注意子る必琹がある。こ机については，筆 者らの研究グループが文献 [12][16][17]で既に 報告して扮り，タスク分割数が多くなると通 信の遅延が酷くなるのではなく，オブジェク 卜其有空間に刘古るアクセ久負荷が猧度にな る。つまり，エントリの読み書き操作に過度 の時間を費やすため，システム全体の性能低 下をまねくのである。そのため，多様性維持 能力とシステム性能の関倸を考慮し, 不必要 に部分集団数を多くしない手法や，オブジェ クト共有空間を複数の計算機に分割しアクセ 又負得老低減する手法などを模討寸る必要が ある。

以上の結果加，提案手法は，比較的単純な 遗伝的操作にも係わらず多様性維持の点で充 分に優机ているものと考えられる。したがっ て，この提案手法を朋いることにより，過剩 収束による准化の停滞を特に意識することな くGAの処理を勧現することが可能となる.

\section{5 おわりに}

本論文では，オブジェクト共有岱間を朋い たワーカ複鄨形式に上る分散並列処理を複数 集団型島モデル椪列 GA に応用する手法を提 案した。また，組み合わせ最適化問題の典型 であるナップザック問題を題材に取り上げ，工
リート個体移住による多様性維持の效果，お よび探索解空間搪大による多様性維持の効果 老確認与る予備实験在行い，過剩収束回邀の 必琶性を示した。そして，できる限り単純な 仕組みで過剩収束走回遊する手法として，， アの箱舟戦略を提案し実験的評何在行った。 実験の結果，提案手法により，比較的単純な 遺伝的操作にも倸わらず充分に多様性老維持 することができた。したがって，この提叠手 法を用いることにより，過剩収束による谁化 の停滞を特に意識することなく GAの処理を 実現することが可能となる。また，適切に初 期海集団(夕スク) を分割すれ枯，提案手法は 過㮃収束による淮化の停滞が起こりにくい真 荷分散による高速化も期待できる。

本論文では，一貫してナップザック問題を 対象として実騃を行ったが，今後は提案した 多様性維持手法をその他の最適化問題に適用 しさらなる評韽を行う予定である。

\section{参考文献}

[1] D. E. Goldberg: 'Genetic Algorithms in Search, Optimization, and Machine Learning", Addison-Wesley (1989).

[2]北野宏明：「遗伝的アルゴリズム」，産業 図青 (1993).

[3] 三宮信夫；喜多一; 王置久; 岩本貴司： 「遺伝アルゴリズムと最適化」, 朝倉畫店 (1998).

[4] R. Tanese: "Distributed Genetic Algorithm", Proceedings of the Third International Conference on Genetic Algorithms, pp. 434-439 (1989).

[5] T., Starkweather; D., Whitley; and K.. Mathias: "Optimization Using Distributed Genetic Algorithms". Parallel Problem Solving from Nature, SpringerVerlag, pp. 176185 (1990).

[6] M.. Munetono: Y.. Takai; and Y.. Sato: "An Efficient Migration Scheme for Subpopulation-Based Asynchronously 
Parallel Genetic Algorithms", Proceedings of the Fifth International Conference on Genetic Algorithms, p. 649 (1993).

[7] 棟朝雅晴; 高井昌彰; 佐藤義治：「集団 分割型非同期並列遺伝的アルゴリズムに おける個体交換アルゴリズムの改良と評 俩」, 情報処理学会論文誌, Vol. 35, No. 9, pp. 1815-1827 (1994).

[8] T., C., Belding: "The Distributed Genetic Algorithm Revisited", Proceedings of the Sixth International Conference on Genetic Algorithms, pp. 114121 (1995).

[9] 堀井宏鿆; 小泉孝之; 过内伸好; 國藤進: 「複数の朢なる遺伝パラメータを持つ GA によるパラメー夕感度低減化法の提案」, 日本機会学会第 9 回計算力学講演会講演 論文集，No. 96-25，pp. 1-2 (1996).

[10] D., Gelernter: "Generative Communication in Linda", ACM Trans. Program. Lang. Syst., Vol. 7, No. 1, pp. 80-112 (1985).

[11] E., Freeman; S., Hupfer; and K., Arnold: "JavaSpaces Principles, Patterns, and Practice". Addison-Wesley (1999).

[12] 曲井薗隆也；中目茂：「オブジェクト共 有空間 JavaSpacesに招沙分散並列処 理の実験評亚」，電子情報通信学:会技術報 告, Vol. 99, No. 547, SS99-59, pp. 73-80 (2000).

[13] 伊庭斉志：「進化論的計算の方法」, 東京 大学出版会 (1999).

[14]松井和宏：「遺伝的アルゴリズムにおける 多様性維持のための個体間相関選択」, 電子情報通信学会論文誌, D-I, Vol. J84D-I, No. 2, pp. 212-236 (2001).

[15] 戸谷智之; 不川翰人：「マルチ個体群の 证列遺伝的アルゴリズムを用いたタンパ ク質の配列解析」, 情報処理学会論文誌, Vol. 36, No. 11, pp. 2549-2558 (1995).
[16] 由井薗隆也; 西省吾; 森邦彦; 中山茂： 「フレネル型計算機ホログラムの高速計算 のための分散並列処理」, 光学: Vol. 29, No. 5, pp. 316-322 (2000).

[17] 鶴沢偉伸; 中山茂; 㴊田孝康; 村島定行： 「楕円曲線法に㧍ける素因数分解高速化 のための分散亚列処理実験」, 電気学:会論 文誌，Vol. 122-C，No. 5, pp. 885-891 (2002).

(2003 年 1 月 10 日受付) (2003 年 4 月 15 日採録)

\section{A 実験で使用したナップザック問題 の詳細なデータ}

乱数により生成された品物 500 個分の重量 と洒値からなるナップザック問題の詳細なデー 夕を，付表 A.1，付表 A.2 に示す。このデー 夕は，本論文の全実験に扔いて共通に使用さ れたものである。 
表 A.1 品物 500 個分の重量と偭値からなる間題デー夕 (No.0〜No.249)

\begin{tabular}{|c|c|c|c|c|c|c|c|c|c|c|c|c|c|c|}
\hline No. & Weight, & Value & No. & Weight & Value & No. & Weight & Value & No. & Weight & Value & No. & Weight & Value \\
\hline 0 & 487 & 186 & 50 & 355 & 405 & 100 & 178 & 85 & 150 & 290 & \begin{tabular}{|l|}
433 \\
\end{tabular} & 200 & 30 & 458 \\
\hline 1 & 188 & 126 & 51 & 477 & 388 & 101 & 84 & 362 & 151 & 195 & 404 & 201 & 165 & 237 \\
\hline 2 & 87 & 429 & 52 & 361 & 37 & 102 & 344 & 225 & 152 & 427 & 276 & 202 & 329 & 149 \\
\hline 3 & 226 & 476 & 53 & 49 & 197 & 103 & 378 & 329 & 153 & 133 & 205 & 203 & 469 & 394 \\
\hline 4 & 120 & 44 & 54 & 138 & 359 & 104 & 425 & 6 & 154 & 451 & 341 & 204 & 437 & 170 \\
\hline 5 & 443 & 152 & 55 & 46 & 60 & 105 & 179 & 403 & 155 & 53 & 322 & 205 & 136 & 166 \\
\hline 6 & 493 & 37 & 56 & 463 & 429 & 106 & 411 & 1 & 1.56 & 242 & 41 & 206 & 230 & 392 \\
\hline 7 & 373 & 113 & 57 & 163 & 446 & 107 & 336 & 99 & 157 & 159 & 457 & 207 & 281. & 69 \\
\hline 8 & 93 & 316 & 58 & 295 & 330 & 108 & 80 & 43 & 158 & 181 & 464 & 208 & 243 & 432 \\
\hline 9 & 499 & 327 & 59 & 427 & 265 & 109 & 229 & 226 & 159 & 463 & 366 & 209 & 139 & 106 \\
\hline $10^{-}$ & 253 & 339 & $60^{-}$ & 469 & 439 & 110 & 394 & 140 & 160 & 113 & 358 & 210 & 458 & 79 \\
\hline 11 & 233 & 269 & 61 & 449 & 455 & 111 & 281. & 176 & 161 & 485 & 242 & 211 & 418 & 118 \\
\hline 12 & 353 & 175 & 62 & 7 & 98 & 112 & 402 & 336 & 162 & 252 & 195 & 212 & 71 & 282 \\
\hline 13 & 479 & 477 & 63 & 286 & 221 & 113 & 251 & 385 & 163 & 265 & 158 & 213 & 56 & 466 \\
\hline 14 & 199 & 68 & 64 & 438 & 35 & 114 & 389 & 404 & 164 & 168 & 255 & 214 & 478 & 167 \\
\hline 15 & 420 & 7 & 65 & 173 & 196 & 115 & 81 & 92 & 165 & 163 & 81 & 215 & 281 & 86 \\
\hline 16 & 391 & 402 & 66 & 212 & 48 & 116 & 11. & 16 & 166 & 448 & 318 & 216 & 298 & 316 \\
\hline 17 & 227 & 212 & 67 & 321 & 302 & 117 & 184 & 148 & 167 & 213 & 407 & 21.7 & 333 & 448 \\
\hline 18 & 338 & 58 & 68 & 271. & 29 & 11.8 & 366 & 408 & 168 & 470 & 24 & 218 & 492 & 45 \\
\hline 19 & 357 & 499 & 69 & 209 & 272 & 119 & 402 & 443 & 169 & 485 & 116 & 219 & 359 & 457 \\
\hline 20 & 470 & 489 & 70 & 168 & 17 & $120^{-}$ & 450 & 481 & 170 & $91^{-}$ & 245 & $220^{-}$ & $286^{-}$ & 70 \\
\hline 21 & 383 & 42 & 71 & 421 & 86 & 121 & 348 & 341 & 171 & 334 & 393 & 221 & 259 & 2 \\
\hline 22 & 84 & 348 & 72 & 255 & 27 & 122 & 119 & 424 & 1.72 & 386 & 77 & 222 & 183 & 227 \\
\hline 23 & 467 & 460 & 73 & 380 & 256 & 123 & 268 & 389 & 173 & 316 & 249 & 223 & 458 & 437 \\
\hline 24 & 477 & 176 & 74 & 93 & 42 & 124 & 112 & 250 & 174 & 184 & 2 & 224 & 339 & 465 \\
\hline 25 & 389 & 62 & 75 & 421 & 369 & 125 & 280 & 207 & 175 & 124 & 139 & 225 & 14 & 251 \\
\hline 26 & 335 & 184 & 76 & 340 & 313 & 126 & 356 & 211 & 176 & 398 & 383 & 226 & 209 & 186 \\
\hline 27 & 127 & 80 & 77 & 207 & 475 & 127 & 454 & 150 & 177 & 98 & 32 & 227 & 493 & 308 \\
\hline 28 & 268 & 446 & 78 & 498 & 96 & 128 & 67 & 149 & 178 & 266 & 258 & 228 & 365 & 360 \\
\hline 29 & 122 & 371 & 79 & 423 & 482 & 129 & 95 & 317 & 179 & 10 & 457 & 229 & 67 & 163 \\
\hline 30 & 125 & 398 & 80 & 359 & 397 & 130 & 454 & 396 & 180 & 219 & 414 & 230 & 13 & 482 \\
\hline 31 & 50 & 401 & 81 & 31 & 289 & 131 & 47 & 389 & 181 & 150 & 32 & 231 & 128 & 428 \\
\hline 32 & 204 & 423 & 82 & 45 & 387 & 132 & 44 & 232 & 182 & 162 & 119 & 232 & 51 & 476 \\
\hline 33 & 457 & 145 & 83 & 448 & 327 & 133 & 22 & 381 & 183 & 486 & 112 & 233 & 340 & 119 \\
\hline 34 & 244 & 408 & 84 & 445 & 374 & 134 & 484 & 7 & 184 & 85 & 118 & 234 & 228 & 418 \\
\hline 35 & 255 & 480 & 85 & 403 & 499 & 135 & 137 & 487 & 185 & 465 & 294 & 235 & 121 & 250 \\
\hline 36 & 14 & 147 & 86 & 226 & 1.29 & 1.36 & 216 & 53 & 186 & 136 & 20 & 236 & 121 & 338 \\
\hline 37 & 438 & 101 & 87 & 38 & 97 & 137 & 112 & 471 & 187 & 416 & 478 & 237 & 359 & 179 \\
\hline 38 & 22 & 126 & 88 & 124 & 474 & 138 & 417 & 390 & 188 & 153 & 376 & 238 & 483 & 111 \\
\hline 39 & 61 & 162 & 89 & 418 & 373 & 139 & 385 & 122 & 189 & 262 & 91 & 239 & 264 & 45 \\
\hline 40 & 304 & 394 & 90 & 31 & 92 & 140 & 78 & 220 & 190 & 182 & 278 & 240 & 282 & 457 \\
\hline 41 & 328 & 499 & 91 & 256 & 363 & 141 & 295 & 469 & 191 & 170 & 256 & 241 & 251. & 53 \\
\hline 42 & 133 & 277 & 92 & 178 & 407 & 142 & 127 & 298 & 192 & 61 & 304 & 242 & 155 & 86 \\
\hline 43 & 83 & 4.9 & 93 & 216 & 430 & 143 & 32 & 480 & 193 & 106 & 148 & 243 & 107 & 218 \\
\hline 44 & 158 & 59 & 94 & 15 & 311 & 144 & 207 & 346 & 194 & 426 & 423 & 244 & 54 & 422 \\
\hline 45 & 187 & 427 & 95 & 137 & 133 & 145 & 1 & 338 & 195 & 189 & 453 & 245 & 80 & 266 \\
\hline 46 & 479 & 5 & 96 & 311 & 495 & 146 & 361 & 90 & 196 & 333 & 250 & 246 & 359 & 60 \\
\hline 47 & 233 & 353 & 97 & 436 & 168 & 147 & 227 & 123 & 197 & 423 & 30 & 247 & 434 & 27 \\
\hline 48 & 86 & 459 & 98 & 11 & 22 & 148 & 4 & 193 & 198 & 244 & 67 & 248 & 245 & 290 \\
\hline 49 & 66 & 379 & 99 & 125 & 259 & 149 & 323 & 270 & 199 & 30 & 58 & 249 & 267 & 458 \\
\hline
\end{tabular}


表 A.2 品物 500 個分の重荲と価值からなる問題デー夕 (No.250－No.499)

\begin{tabular}{|c|c|c|c|c|c|c|c|c|c|c|c|c|c|c|}
\hline No. & Weight & Value & No. & Weight & Value & No. & Weight & Value & No. & Weight & Value & No. & Weight & $\begin{array}{l}\text { Value } \\
\end{array}$ \\
\hline 250 & 145 & 280 & 300 & 488 & 29 & 350 & 160 & 323 & 400 & 316 & 314 & 450 & 486 & 471 \\
\hline 251 & 316 & 402 & 301 & 307 & 207 & 351 & 34 & 229 & 401 & 363 & 190 & 451 & 48 & 389 \\
\hline 252 & 413 & 456 & 302 & 358 & 50 & 52 & 114 & 304 & 402 & 74 & 486 & 452 & 25 & 83 \\
\hline 253 & 336 & 53 & 303 & 168 & 182 & 353 & 44 & 251 & 403 & 353 & 425 & 453 & 82 & 135 \\
\hline 254 & 309 & 433 & 304 & 100 & 186 & 354 & 95 & 2 & 404 & 476 & 424 & 454 & 318 & 237 \\
\hline 55 & 11 & 41 & 305 & 464 & 417 & 355 & 238 & 33 & 405 & 410 & 273 & 455 & 304 & 79 \\
\hline 256 & 36 & 333 & 306 & 364 & 173 & 356 & 95 & 369 & 406 & 486 & 23 & 456 & 52 & 349 \\
\hline 257 & 381 & 98 & 307 & 269 & 16 & 357 & 495 & 345 & 407 & 404 & 273 & 457 & 9 & 492 \\
\hline 258 & 215 & 317 & 8 & 94 & 413 & 358 & 327 & 249 & 408 & 46 & 498 & 458 & 492 & 317 \\
\hline 259 & 291 & 184 & 309 & 256 & 326 & 359 & 496 & 180 & 409 & 230 & 189 & 459 & 343 & 276 \\
\hline $260^{-}$ & 223 & 38 & 310 & 32 & 244 & $360^{\circ}$ & 131 & 240 & 410 & 319 & 398 & 460 & $160^{\circ}$ & 189 \\
\hline 261 & 153 & 100 & 11 & 422 & 117 & 361 & 336 & 321 & 411 & 59 & 156 & 461 & 108 & 427 \\
\hline 262 & 89 & 262 & 2 & 345 & 344 & 362 & 116 & 391 & 412 & (190) & 248 & 462 & 68 & 41 \\
\hline 263 & 135 & 372 & 13 & 233 & 124 & 363 & 192 & 394 & 413 & 333 & 347 & 403 & 314 & 56 \\
\hline 264 & 19 & 46 & 4 & 290 & 234 & 364 & 327 & 226 & 414 & 208 & 98 & 464 & 68 & 28 \\
\hline & 6 & 93 & & 492 & 199 & 5 & 185 & 376 & 415 & 494 & 39 & 46 & 290 & 205 \\
\hline 2 & 1 & 254 & & 51 & 367 & 6 & 340 & 49 & 16 & 97 & 80 & 4 & 31 & 434 \\
\hline 267 & 8 & 66 & & 90 & 70 & 367 & 97 & 217 & 417 & 403 & 481 & 8 & 46 & 364 \\
\hline 268 & & 429 & 8 & 456 & 413 & 368 & 289 & 260 & 418 & 81 & 291 & 468 & 10 & 35 \\
\hline 2 & 41. & 9 & 9 & 404 & 184 & 369 & 322 & 11 & 419 & 357 & 49 & 469 & 241. & 385 \\
\hline & & 256 & 0 & & 258 & $370^{\circ}$ & 191 & 253 & 420 & $380^{-}$ & 338 & 470 & $86^{\circ}$ & 14.7 \\
\hline 2 & 299 & 100 & 21 & $y$ & 219 & 371 & 327 & 242 & 421 & 425 & 324 & 471 & 57 & 408 \\
\hline 27 & 72 & 98 & 322 & 105 & 242 & 372 & 27 & 169 & 422 & 228 & 97 & 4 & $4 \sqrt{2}$ & 190 \\
\hline $27:$ & 3 & 21 & 323 & 1. & 113 & 373 & 17 & 91 & $42:$ & 47 & 68 & 4 & 77 & 403 \\
\hline & & 83 & 324 & 4 & 16 & 374 & & 81 & 42 & 435 & 235 & 474 & 11 & 442 \\
\hline & & 79 & 5 & & 493 & 375 & 410 & 77 & 425 & 10 & 255 & 75 & 65 & 395 \\
\hline 276 & & 370 & 26 & 249 & 321 & 376 & 152 & 369 & 426 & 277 & 163 & 476 & 48 & 43 \\
\hline & & 470 & 7 & 18 & 164 & 377 & 53 & 394 & 427 & 472 & 21.4 & 477 & 02 & 184 \\
\hline & & 56 & 28 & 204 & 460 & 378 & 269 & 44 & 428 & 199 & 179 & 478 & 333 & 187 \\
\hline & & 295 & & 76 & 265 & 379 & 457 & 120 & 429 & 81 & 344 & 4 & 67 & 387 \\
\hline 28 & & 231 & ; & 160 & 365 & 380 & 154 & 438 & 430 & 93 & 25 & 480 & 312 & 331 \\
\hline & 229 & 457 & $:$ & 327 & 412 & 381 & 83 & 421 & 43 & 3 & 382 & 481 & 433 & 278 \\
\hline 2 & & 1.88 & 332 & 299 & 290 & 382 & 44 & 201. & 432 & 467 & 89 & 482 & 51 & 42 \\
\hline 283 & 265 & 97 & 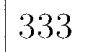 & 344 & 378 & 383 & 451 & 180 & 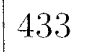 & 269 & 471 & 483 & 180 & 92 \\
\hline & 31 & 330 & 3 & & 226 & 384 & 82 & 374 & 434 & 42 & 57 & 484 & 30 & 229 \\
\hline 285 & & 205 & 335 & & 433 & 385 & 195 & 117 & 435 & 484 & 42 & 485 & 91 & 18 \\
\hline 286 & & 448 & 336 & 189 & 2 & 386 & & 341 & 436 & 415 & 83 & 486 & 429 & 447 \\
\hline 287 & & 187 & 3 & 21 & 53 & 387 & 324 & 305 & 437 & 347 & 304 & 487 & 495 & 358 \\
\hline 28 & & 114 & : & & 479 & 388 & 4 & 497 & 438 & 24 & 364 & 488 & 308 & 384 \\
\hline 289 & & 98 & : & 4 & 68 & 389 & & 204 & 439 & 403 & 340 & 489 & 101 & 258 \\
\hline 290 & & 135 & 3 & & 176 & 390 & & 200 & 440 & 308 & 200 & 490 & 413 & 86 \\
\hline & & 475 & 341 & & 275 & 391 & & 200 & 44 & 199 & 313 & 491 & 177 & 449 \\
\hline 10 & & 11 & 342 & & 394 & 392 & 1 & 453 & 442 & 170 & 415 & 492 & 96 & 471 \\
\hline 293 & 287 & 466 & 343 & & 385 & 393 & & 39 & 443 & 239 & 416 & 493 & 318 & 379 \\
\hline 294 & - & 32 & 344 & & 400 & 394 & 422 & 304 & 444 & 233 & 179 & 494 & 299 & 302 \\
\hline 295 & & 395 & 345 & 423 & 489 & 395 & & 465 & 445 & 288 & 231 & 495 & 242 & 378 \\
\hline 296 & 378 & 407 & 346 & 176 & 64 & 396 & & 150 & 446 & 448 & 65 & 496 & 353 & 248 \\
\hline 297 & 391 & 468 & 347 & 73 & 452 & 397 & 159 & 491 & 447 & 131 & 249 & 497 & 116 & 478 \\
\hline 298 & 86 & 99 & 348 & 224 & 176 & 398 & 232 & 186 & 448 & 379 & 35 & 498 & 270 & 71 \\
\hline 299 & 180 & 369 & 349 & 70 & 368 & 399 & 431 & 88 & 449 & 206 & 383 & 499 & 466 & 125 \\
\hline
\end{tabular}

